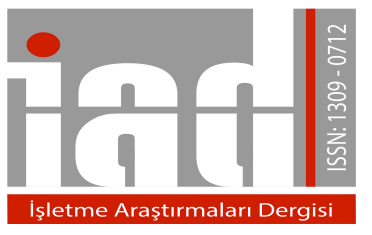

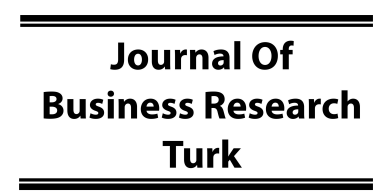

www.isarder.org

\title{
Çalışanların Olumsuz Değerlendirilme Korkusunun Örgütsel Sessizlik Üzerine Etkisi \\ Effect of Fear of Negative Evaluation of Employees \\ on Organizational Silence
}

\author{
Engin KANBUR \\ Kastamonu Üniversitesi \\ Sivil Havacilık Yüksekokulu \\ Havacılık Yönetimi \\ Kastamonu, Türkiye \\ orcid.org/0000-0002-6261-9314 \\ ekanbur@,kastamonu.edu.tr
}

\begin{abstract}
Özet
Çalışanlar, örgüt ile ilgili sorun veya firsat içeren durumlarda, kendilerini gelebilecek zarar ve tehlikelerden korumak, dışlanmak ve değersizleşmekten kaçınmak için bilinçli olarak sessiz kalma davranışı sergileyebilmektedirler. Araştırmanın temel amacı, çalışanların olumsuz değerlendirilme korkusunun örgütsel sessizlik düzeyleri üzerine olan etkisinin incelenmesidir. Araştırmanın evreni, Kastamonu il merkezinde bulunan bir kamu kurumunda görev yapan 120 çalışandan oluşmaktadır. Araştırmada, olumsuz değerlendirilme korkusu ölçeği ve örgütsel sessizlik ölçeği kullanılmıştır. Araştırma ölçeklerinin iç tutarlılık analizi Cronbach Alfa ile incelenmiş ve \% 70 'in üzerinde tespit edilmiş̧ir. Ayrıca ölçekler doğrulayıcı faktör analizi sonucu iyi uyum değerleri göstermiş̧tir. Değişkenler arasındaki ilişkiyi ortaya koymak amacıyla korelasyon analizi ve regresyon analizi kullanılmıştır. Araştırmanın bulguları değerlendirildiğinde; olumsuz değerlendirilme korkusunun örgütsel sessizlik ve boyutları (kabullenici, korunma) ile güçlü, anlamlı ve pozitif bir ilişkisinin olduğu görülmektedir. Ancak koruma amaçlı sessizlik ile herhangi bir ilişkiye rastlanmamıştır.
\end{abstract}

Anahtar Kelimeler: Olumsuz değerlendirilme korkusu, örgütsel sessizlik, kabullenici sessizlik, korunma amaçlı sessizlik, koruma amaçlı sessizlik.

\section{Abstract}

Employees, when encountered to a problem or an opportunity, may consciously exhibit silence behavior in order to protect themselves from harm and danger that may arise and to avoid from being excluded and being worthless. The main purpose of the research is to examine the effect of employees' fear of negative evaluation on their organizational silence levels. The population of the research consists of 120 employees working in a public institution located in Kastamonu province city center. "Fear of Negative Evaluation Scale" and "Organizational Silence Scale" were used in the research. The internal consistency analyses of the scales were examined with Cronbach Alpha and found over 70\%. Additionally, confirmatory factor analysis results of the 
scales showed good fit values. Correlation and regression analyses were conducted for understanding the relationships between variables. When the findings of the research are evaluated; there appears to be a strong, significant and positive relationship between the fear of negative evaluation and organizational silence and its subdimensions (acquiescent silence and defensive silence). However, no relation is observed between the prosocial silence.

Keywords: Fear of negative evaluation, organizational silence, acquiescent silence, defensive silence, prosocial silence.

\section{Giriş}

Örgütler, yoğun rekabetin yaşandığı küresel iş dünyasında tüketicilerin beklentilerini kaliteden ödün vermeden en iyi ve hızlı şekilde karşılamak, rakiplerine karşı sürdürülebilir rekabet avantajı yakalamak, sektörde lider konuma gelmek ve olumlu bir imaj yaratmak için bilgili ve bunu paylaşmaktan korkmayan, tecrübeli, sorumluluk alan, yaratıcı, girişimci, aidiyetli ve yenilikçi çalışanlara ihtiyaç duymaktadır (Quinn ve Spreitzer, 1997). Çalışanların bu becerilere sahip olması ve örgüt içinde rahat ve özgür bir biçimde kullanabilmesi örgütsel ve yönetsel bazı engellerin kaldırılması, olumlu örgüt kültürü yaratılması ve örgüt tarafindan gerekli desteğin sağlanması ile mümkün olabilmektedir (Dimitris ve Vakola, 2007).

Çalışanlar, kendilerine değer verildiği, kararlara katılımlarının sağlandığı, fikir, düşünce ve bilgilerin özgürce paylaşıldığı, davranışlarından dolayı küçümsenmediği, örgütsel adaletin tam olarak sağlandığı örgütlerde daha etkili ve verimli bir şekilde çalışabilmekte ve dolayısıyla performansları yüksek olabilmektedir. Bunun tam tersi durumlarda ise çalışanlar, örgüt ile ilgili sorun veya firsat içeren durumlarda kendilerini gelebilecek zarar ve tehlikelerden korumak, dışlanmak ve değersizleşmekten kaçınmak için bilinçli olarak sessiz kalma davranışı sergileyebilmektedirler. Olumsuz değerlendirilme korkusu çalışanların olaylar karşısında sessiz kalma, konuşmama ve/veya tepkisiz kalma davranışının temelini oluşturan faktörlerden biridir (Milliken ve Morrison, 2003).

Olumsuz değerlendirilme korkusu, bireyin performansı, yetenekleri ve davranışları hakkında başkalarının olumsuz değerlendirmelerini göz önünde bulundurması, bunlardan dolayı sıkıntı, endişe ve korku yaşaması ve bu tür ortamlardan kaçınması şeklinde tanımlanmaktadır (Erdoğan ve Uçukoğlu, 2011; Leary, 1983). Örgütsel sessizlik ise çalışanların bilinçli, aktif ve bir amaca yönelik olarak gerçekleştirdiği davranış şekli olarak belirtilebilir. Örgütsel sessizlik; örgütsel değişimi ve gelişimi etkileyebilme ve sorunları çözümleyebilme yeteneğine sahip olan yönetici, patron, lider ve diğer bireylere karşı çalışanların, davranışsal, duygusal ve/veya bilişsel değerlendirmeleri konusunda fikirlerini, düşüncelerini ve bilgilerini gizlemesi, söylememesi olarak da tanımlanmaktadır (Çakıc1, 2008; Erigüç ve diğ., 2014). Modern yönetim yaklaşımları kapsamında çalışanların yaratıcılıkları, iç girişimcilik özellikleri, bilgi ve düşünlerinin daha fazla paylaşılması, örgütsel bağlılık ve iş tatminin yüksek olması ve dolayısıyla örgütsel performansın artması beklenirken, yaşanan çeşitli sebeplerden dolayı çalışanların örgüte karşı bilinçli bir şekilde kayıtsız ve sessiz kaldıkları görülmektedir. Çalışanların sergiledikleri bu sessiz kalma davranışı yeni ve yaratıcı fikirlerin ortaya çıkmasını ve sinerjinin oluşmasını olumsuz olarak etkilemektedir (Çavuşoğlu ve Köse, 2016). 
Bu çalışmada, çalışanların olumsuz değerlendirilme korkusunun örgütsel sessizlik düzeyleri üzerine olan etkisinin incelenmesi amaçlanmaktadır. Bu doğrultuda öncelikle iki kavramın daha iyi anlaşılması için ilgili yazın taraması yapılmış ve araştırma hipotezleri oluşturulmuştur. Araştırmanın metodolojisi kapsamında; araştırmanın evreni, örneklemi, kısıtları, kullanılan ölçekler açıklanmış ve geçerlilik ve güvenirlilik analizleri yapılmıştır. Bulgular kısmında ise, değişkenler arasındaki ilişkiyi ortaya koymak amacıyla korelasyon analizi ve regresyon analizi kullanılmıştır. Daha sonra ise bulgular 1şığında sonuç ve değerlendirmeler yapılarak önerilerde bulunulmuştur.

\section{Kavramsal Çerçeve}

Bu bölümde, olumsuz değerlendirilme korkusu ve örgütsel sessizlik kavramları ile ilgili yazın taraması ve bu iki kavram arasındaki ilişkiye yer verilmektedir.

\subsection{Olumsuz Değerlendirilme Korkusu}

İnsanlar sosyal varlıklardır ve birbirleri ile etkileşim içindedirler. Bu etkileşim sürecinde diğerleri üzerinde nasıl bir etki bıraktıkları ve diğerleri tarafından nasıl algılandıkları veya değerlendirildikleri ile ilgilenirler. Bu algılamalar hem olumlu hem de olumsuz olabilir (Çam, Sevimli ve Yerlikaya, 2010). Sosyal bir ortamda diğer bireylerle bir arada olmaktan, aynı ortamı paylaşmaktan huzursuz olma, bu tür ortamlardan kaçınma, sıkılma ve utangaçlık gösterme ve diğerleri tarafından olumsuz değerlendirilme korkusunu yaşama gibi durumlar sosyal kaygı veya sosyal fobi olarak tanımlanmaktadır (Doğan ve Totan, 2010). Sosyal kaygı, kişinin iş ve sosyal yaşamında sergileyeceği performansı engelleyen ve bilişsel nedenleri araştırıldığında özünde olumsuz değerlendirilme korkusunun olduğu yaşam kalitesini kısıtlayıcı ve zorlayıcı bir hastalıktır (Duke ve diğ., 2006).

Sosyal kaygıyı en iyi açıklayan modellerden biri de bilişsel model olarak belirtilmektedir. Bu modele göre sosyal kaygının en belirgin özelliği; kişinin diğer insanların gözünde güçlü bir olumlu algı ve izlenim bırakma amacının olması fakat bu amacı yerine getirebilecek yeteneğine ve bilgisine karşı güvensizlik duymasıdır (Çam ve diğ., 2010). Sosyal kaygı yaşayan birey, diğerleri ile birlikteyken istenmeyen, ayıplanan davranışlar içerisinde olacağı ve bunun sonucunda diğerleri tarafından kabul edilmeyeceği, değer ve itibar kaybına sebep olabileceği ve bireysel amaçlarına ulaşamayacağı gibi düşünceler içerisinde olur (Türkçapar, 1999). Dolayısıyla sosyal kaygı, utangaçlık, şüphe duyma, endişelenme, korku gibi bireyin performansını kısıtlayan, iletişim becerisini engelleyen, beslenme alışkanlıklarını düşüren ve öz güvenini azaltan nedenlerin temelinde olumsuz değerlendirilme korkusu yer almaktadır (Amico ve diğ., 2003; Beidel, Morris ve Turner, 2004; Carleton, Collimore ve Asmundson, 2007; Durmuş, 2008; Hamarta, 2009; Ünal, Arık ve Uzun, 2016). Sosyal kaygı ve olumsuz değerlendirilme korkusu, kişilerarası ilişkilerin bozulması, güvensizlik ve depresyon da dâhil olmak üzere birçok istenmeyen ve kritik sonuçlar için önemli risk faktörleridir (Teachman ve Allen, 2007).

Olumsuz değerlendirilme korkusu (ODK), bireyin performansı, yetenekleri ve davranışları hakkında başkalarının olumsuz değerlendirmelerini gözönünde bulundurması, bunlardan dolayı sıkınt1, endişe ve korku yaşaması ve bu tür ortamlardan kaçınması şeklinde tanımlanmaktadır (Erdoğan ve Uçukoğlu, 2011; Leary, 1983). Watson ve Friend (1969) ODK'yı, bireyin başkalarının değerlendirmeleriyle ilgili duyduğu endişe, olası olumsuz değerlendirmelerine karş1 üzülme ve yaptığı veya yapacağı davranışlardan ötürü olumsuz değerlendirilme beklentisi içinde olma durumu 
olarak tanımlamaktadır (Ayan ve Ünsar, 2015; Begley ve White, 2003; Collins ve. diğ., 2005; Mesagno, Harvey ve Janelle, 2012; Ridgers, Fazey ve Fairclough, 2007). ODK, sergileyeceği faaliyetlerde başkalarından onay almama veya olumsuz geri bildirim alma ihtimalinden kaynaklanan endişe ve korku olarak tanımlanabilir (Amico ve diğ., 2003). ODK, bireyin potansiyelinin düşük seviyede olduğunun ortaya çıkması ve başkalarının bu durumu olumsuz değerlendirmesinin farkındalı̆̆ıdır (Özgüngör, 2006). Bu nedenle ODK, küçük düşürülme, olası düşmanca davranışlardan kaynaklı üzüntü, kaygı ve korku halidir (Köse ve diğ., 2016; Sevimli, 2009; Weeks, Heimberg ve Rodebaugh, 2008).

ODK, genel korkular, endişe ve psikopatolojilerin gelişimini desteklediğine inanılan üç temel korkudan biridir (Carleton ve diğ., 2007). ODK, kişinin; sosyal bir faaliyet içindeyken başkaları tarafından olumsuz değerlendirileceğine ve ondan yüksek performans beklendiğine, kabiliyeti ve performansı konusunda şüpheye kapılmasına ve olası bir hata durumunda dışlanacağı, ayıplanacağı ve yetersiz görüleceğine dair birtakım inançlar geliştirmesine sebep olmaktadır (Çetin, İlhan ve Yılmaz, 2014; Rapee ve Heimberg, 1997; Weeks ve diğ., 2005). ODK, başkalarından sosyal onay alma veya onaylanma çabası ile ilgili olduğundan ODK'sı yüksek olan bireylerin onay alma ya da onaylanmamaktan kaçınma veya endişe duyma güdüleri oldukça yüksektir (Erkan, 2002). Bireyin sosyal bir ortamdayken devamlı olarak hata yapıp çevresinde bulunan diğer bireylerden olumsuz değerlendirmeler alabileceği düşüncesi onun performansını düşürebilir ve bu tür sosyal ortamlarda rahat davranmasını ve kendini ifade edebilmesini engelleyebilir (Ömür, Aydın ve Argon, 2014).

ODK ile ilgili yazında yapılan çalışmaların bazıları kavramın daha iyi anlaşılması ve yazındaki diğer değişkenler ile olan ilişsisini ortaya koyması bakımından önemli olabilir. Puklek ve Vidmar (2000) araştırmalarında, olumsuz değerlendirilme korkusunun erkeklere oranla kadınlarda daha fazla görüldüğünü ve yaş artıkça azaldığı sonucunu ortaya koymuşlardır. Aydın (2008) araştırmasında, yabancı dil öğrencilerinin dil kaygılarının (konuşma, yanlış anlaşılma gibi) en güçlü kaynağının başkaları tarafindan olumsuz değerlendirme korkusu olduğunu belirtmişlerdir. Seçer, Halmatov ve Gençdoğan (2013) çalışmalarında, olumsuz değerlendirilme korkusu ile sosyal kaçınma, kritize edilme korkusu ve değersizlik duygusu arasında pozitif ve anlamlı bir ilişkinin olduğunu saptamışlardır. Zorbaz ve Dost (2014) çalışmalarında, olumsuz değerlendirilme korkusu ile bağlılık, güven ve özdeşim arasında negatif ve anlamlı bir ilişkinin olduğunu ortaya koymuşlardır. Bu durumda, bireylerin göstereceği performans sonucu başkaları tarafindan olumsuz değerlendirilme korkusu onların bağl1lık ve güven duymalarını azaltmaktadır. Williams, Falkum ve Martinsen (2015) işitme engelli işgörenler ile gerçekleştirdikleri çalışmalarında, olumsuz değerlendirilme korkusu ile depresyon arasında pozitif ve anlamlı bir ilişkinin olduğunu saptamışlardır. Bireylerin sahip olduğu birtakım engeller (fiziksel, zihinsel) dolayısıyla başkaları tarafından olumsuz değerlendirilebilecekleri düşüncesi ve bunun sonucunda içlerine kapanması onları depresyona girmeye yönelten önemli sebepler arasında yer almaktadır. Çelik ve Odacı (2015) çalışmalarında, akademik erteleme ile olumsuz değerlendirilme korkusu arasında pozitif ve anlamlı bir ilişkinin olduğunu ve bu durumun öğrencilerin başarısını önemli ölçüde etkilediğini vurgulamışlardır. Chu ve diğ. (2016) çalışmalarında, olumsuz değerlendirilme korkusunun yüksek olduğu bireylerde intihara yönelimin de arttığı, dolayısıyla pozitif ve anlamlı bir ilişkinin olduğu sonucuna varmışlardır. Ayrıca, bireyde eksik olan bağlılık duygusu ve inancın, olumsuz değerlendirilme korkusu ile intihar düşüncesi arasındaki ilişskinin açıklayıcısı olduğunu belirtmişlerdir. Yazındaki 
araştırmalar dikkate alındığında ODK'nın çalışanların sergilediği örgütsel sessizlik ile de ilişkili olabileceği düşünülmektedir.

\section{2. Örgütsel Sessizlik}

Sessizlik kavramı Türk Dil Kurumu Büyük Türkçe Sözlüğü’nde en basit anlamıyla "ortamda gürültü (ses) olmama durumu, sükût" olarak tanımlanmaktadır. Sessizlik, konuşmaya yönelik bir davranışın olmaması veya yokluğu olarak belirtilmektedir (Dyne, Ang ve Botero, 2003). Sessizlik kavramı aynı zamanda başkaları ile dayanışma ve uyuşmanın bir göstergesi olarak saygı ve nezaket gösterme, iyi niyet ve tevazu sahibi olma gibi ahlak ve erdem kurallarıyla da yakından ilgilidir (Nakane 2006). Bu durumun aksine katı örgüt yapısı ve kültürü nedeniyle bireylerin yanlış anlaşılma, dışlanma, aşağılanma, iş arkadaşları ve yöneticileri ile çatışma korkusu onların sessiz kalmasına sebep olabilmektedir (Alparslan ve Kayalar, 2012). Sessizlik, genel olarak pasif bir eylemi ifade etmesine rağmen, bu durum tüm sessizlik türleri için aynı değildir (Scott, 1993). Örneğin; bireyler örgütlerinde bazı konularda sessiz kalarak veya konuşmayarak yöneticilere, ekip arkadaşlarına ve diğer ilgili kişilere birtakım mesajlar vermektedirler. Bu bağlamda, bireylerin sessiz kalması o konu hakkında bilgi sahibi olmaması ve/veya düşüncesinin olmadığını göstermemektedir (Acaray, Çekmecelioğlu ve Akturan, 2015).

Örgütsel sessizlik, çalışanların örgütsel performanslarını artırmaya ve işlerini geliştirmeye yönelik sahip oldukları bilgi, düşünce, davranış ve fikirlerini bilinçli olarak ortaya koymaması olarak tanımlanmaktadır (Morrison ve Milliken, 2000; Özyer, 2017). Örgütsel sessizlik; örgüt içindeki istenmeyen ve sorun yaratan durumların giderilebilmesi için gerekli yetenek, bilgi ve yaratıcılığa sahip çalışanların gördükleri ve/veya algıladıkları adaletsizlik ve tehlike karşısında bu becerilerini bilinçli olarak kullanmaması olarak da tanımlanmaktadır (Donaghey ve diğ., 2011; Pinder ve Harlos, 2001). Benzer bir tanımda ise örgütün maruz kaldığı sorunlar ve tehlikeler hakkında kolektif düzeyde herhangi bir davranışta bulunmama veya hiç konuşmama şeklinde ifade edilmektedir (Çakınberk, Dede ve Yılmaz, 2014). Örgütsel sessizliğin hem örgüt hem de çalışanlar üzerinde olumsuz etkileri bulunmaktadır. Örgüt üzerinde; çalışanların bireysel yaratıcılıklarını, iç girişimcilik özelliklerini kullanmaması, sorunları görmemezlikten gelmesi, tecrübelerini ve kabiliyetlerini kullanmaması, iş performansının düşmesi ve verimsizlik gibi etkileri vardır. Çalışan üzerinde ise; iş tatmini, güven, motivasyon, bağlılık ve performansın azalması, kendini çekme ve değersiz hissetme gibi etkileri görülmektedir (Çakıc1, 2008; Milliken ve Morrison 2003).

Çalışanların sessiz kalmalarını gerektiren birtakım nedenler vardır. Bunlar; mevcut duruma ve düşünceye karşı kabullenme davranış1, görüş, düşünce ve fikirlerinin paylaşılması sonucu oluşabilecek tepkiden korkmasına bağlı korunma davranışı ve başkalarını düşünme, ilişki içinde olma ve işbirliği sağlamaya yönelik koruma davranışı olarak belirtilmektedir (Aktaş ve Şimşek, 2014). Bu nedenler aynı zamanda örgütsel sessizliğin boyutlarını oluşturmaktadır. Bunlar; kabullenici sessizlik, korunma amaçlı sessizlik ve koruma amaçlı sessizlik olarak sınıflandırılmaktadır (Dyne ve diğ., 2003; Çakıc1, 2010; Gül ve Özcan, 2011; Karacaoğlu ve Küçükköylü, 2015; Zehir ve Erdoğan, 2011). Kabullenici sessizlik, çalışanların fikir, düşünce, görüş ve bilgilerini kendisine saklaması, bilinçli bir şekilde sessizliğe bürünmesi veya olaylara kayıtsız kayması olarak tanımlanabilir. Çalışanın örgütün içinde bulunduğu sorundan 
kurtulabilmesi için yapılması veya söylenmesi gerekenleri bilmesi fakat bu konuda isteksiz davranması olarak da ifade edilmektedir. Korunma amaçlı sessizlik, çalışanların örgüt içinde kendisine karşı gelebilecek saldırı, zarar ve olumsuz değerlendirmelere karşı kendini savunma davranışından ortaya çıkan bilgi, düşünce ve görüşlerini saklama veya kullanmama olarak tanımlanmaktadır. Korunma amaçlı sessizliğin temelinde korku, endişe ve kaygı gibi faktörler yer almaktadır. Koruma amaçlı sessizlik, çalışanların örgütün ve diğer çalışanların çıkarlarını ön planda tutmak, onlara zarar vermemek veya onlara faydalı olmak için iş ile ilgili bilgi, düşünce ve görüşlerini gizleme veya açığa vurmama olarak tanımlanmaktadır. Koruma amaçlı sessizlikte fedakârlık, özveri ve işbirliği çerçevesinde örgütün ve diğer çalışanların çıkarlarını bilinçli bir şekilde koruma düşüncesi ön plandadır.

Örgütsel sessizlik ile ilgili yazında yapılan çalışmaların bazıları kavramın daha iyi anlaşılması ve yazındaki diğer değişkenler ile olan ilişkisini ortaya koyması bakımından önemli olabilir. Vakola ve Bouradas (2005) çalışmalarında, örgütsel sessizlik ile örgütsel bağlllık, iş tatmini ve iletişim becerileri arasında negatif bir ilişkinin olduğu ve bu durumun çalışanların örgüte karşı aidiyet duygularını, motivasyonlarını ve yaratıcılıklarını azalttığını vurgulamışlardır. Nikmaram ve diğ. (2012), Panahi ve diğ . (2012) ve Aeen, Zarei ve Matin (2014) çalışmalarında örgütsel sessizlik ile örgütsel bağlılık arasında negatif bir korelasyonun olduğunu belirtmektedirler. Fard ve Karimi (2015) de çalışmalarında, örgütsel sessizlik ile iş tatmini ve güven arasında negatif bir ilişkinin olduğunu ortaya koymaktadırlar. Çınar, Karcıoğlu ve Alioğulları (2013), Kılıçlar ve Harbalığlu (2014) ile Korkmaz ve Aydemir (2015) çalışmalarında, örgütsel sessizlik ile örgütsel vatandaşlık davranışı arasında negatif ve güçlü bir ilişkinin olduğunu belirtmektedirler.

Bayın, Yeşilaydın ve Esatoğlu (2015) hemşireler üzerinde örgütsel sessizliğin nedenlerini ortaya koymak amacıyla gerçekleştirdikleri çalışmalarında; örgütsel sessizliğin temel sebebinin örgütsel ve yönetsel faktörler olduğunu vurgulamaktadırlar. Hemşirelerin yaşı, kıdemleri ve çalışma yeri değişiklikleri gibi değişkenlerin sessizlik üzerinde anlamlı bir farklılaşmaya yol açtığ yönelten sebepleri en aza indirmek ve/veya tamamen ortadan kaldırmak için onların düşüncelerini, fikirlerini, görüşlerini rahat ifade edebilecekleri ortamın yaratılması, yöneticilerinin onların endişeleri ve korkuları ile ilgilenmesi ve şeffaf bir örgüt kültürü oluşturması önerilmektedir. Aktaş ve Şimşek (2014) hemşireler üzerinde gerçekleştirdikleri çalışmalarında, örgütsel sessizlik boyutlarından kabullenici sessizlik ile bireysel performans ve boyutları (görev ve bağlamsal) arasında negatif ve anlamlı bir ilişkinin olduğunu vurgulamaktadırlar. Yazarlar başka bir çalışmalarında (2015) ise, örgütsel sessizlik ile iş doyumu arasında negatif bir ilişkinin, tükenmişlik ve boyutları ile pozitif bir ilişkisinin olduğunu belirtmektedirler.

Akın ve Ulusoy (2016) akademisyenler ile gerçekleştirdikleri çalışmalarında, örgütsel sessizlik ile tükenmişlik arasında anlamlı ve pozitif bir ilişkinin olduğunu vurgulamışlardır. Akademik hayatta tükenmişliği en aza indirgemek için yöneticilerin fikirlerin özgürce tartışıldığı, ifade edilebildiği bir örgüt kültürü oluşturması ve bunun devamlılığının sağlanması gerektiği belirtilmektedir. Çavuş, Develi ve Sarığlu (2015) çalışmalarında, örgütsel sessizlik ile mobbing ve boyutları arasında pozitif, anlamlı ve orta düzeyde bir ilişkinin olduğunu vurgulamaktadır. Elçi ve diğ. (2014) çalışmalarında, aynı doğrultuda sonuçlara ulaşmakla beraber çalışmada örgütsel sessizliğin işten ayrılma niyeti üzerinde de pozitif bir ilişkinin olduğunu saptamışlardır. Erol ve Köroğlu 
(2013) liderlik tarzları ile örgütsel sessizlik üzerine gerçekleştirdikleri çalışmalarında, tam serbesti tanıyan ve etkileşimci liderlik tarzları ile örgütsel sessizlik arasında pozitif, dönüşümcü liderlik tarzı ile negatif bir ilişkinin olduğunu ortaya koymaktadırlar. Karacaoğlu ve Küçükköylü (2015) çalışmalarında, örgütsel sessizlik ile örgütsel sinizm arasında pozitif ve güçlü bir ilişkinin olduğunu vurgulamaktadırlar.

\subsection{Olumsuz Değerlendirilme Korkusu ile Örgütsel Sessizlik İlişkisi}

Çalışanlar, sahip olduğu yetenek, kabiliyet, bilgi, düşünce, fikir ve davranışlarından ötürü örgüt ve/veya iş arkadaşları gözünde küçük düşme, aşağılanma, değersizleşme ve bunun gibi olumsuz değerlendirilme korkusu neticesinde endişe, kayg1 ve korku yaşamaktadırlar (Leary, 1983). Olumsuz değerlendirilme korkusu yaşayan çalışanlar örgüt içinde karşılaştıkları olumsuz ve örgüte zarar verebilecek olaylar karşısında sessiz kalmayı tercih etmektedirler (Milliken ve Morrison, 2003). Ayrıca yöneticileri tarafından cezalandırılacağı, iş arkadaşları tarafından dışlanacağı, baskı yapılacağı ve değersizleştirileceği korku ve endişesini taşıyan çalışanlar bilgi, düşünce ve fikirlerini özgürce ifade edemeyecek ve sessizliğe bürüneceklerdir (Akgündüz, 2014; Bowen ve Blackmon, 2003).

Milliken, Morrison ve Hewlin (2003) çalışmalarında, örgütsel sessizliğin en belirgin nedenini, çalışanların, yöneticileri ve/veya iş arkadaşları tarafından olumsuz değerlendirilme korkusu ve bunun sonucunda örgüt içinde kurdukları olumlu ilişkilere zarar verme endişesi ya da kaygısı olarak belirtmektedirler. Bu bağlamda araştırmaya konu olan olumsuz değerlendirilme korkusu ile örgütsel sessizlik ve boyutları arasındaki ilişkiyi ortaya koymak amacıyla aşağıdaki araştırma hipotezleri oluşturulmuştur.

$\mathbf{H}_{1}$ : Çalışanların olumsuz değerlendirilme korkusunun örgütsel sessizlik üzerinde pozitif ve anlamlı bir etkisi vardır.

$\mathbf{H}_{2}$ : Çalışanların olumsuz değerlendirilme korkusunun örgütsel sessizlik boyutlarından "kabullenici sessizlik" üzerinde pozitif etkisi vardır.

H3 $_{3}$ : Çalışanların olumsuz değerlendirilme korkusunun örgütsel sessizlik boyutlarından "korunma amaçlı sessizlik" üzerinde pozitif etkisi vardır.

$\mathbf{H}_{4}$ : Çalışanların olumsuz değerlendirilme korkusunun örgütsel sessizlik boyutlarından "koruma amaçlı sessizlik" üzerinde pozitif etkisi vardır.

\section{Metodoloji}

$\mathrm{Bu}$ bölümde, araştırmanın amacı, önemi, evren ve örneklemi, kısıtları, veri toplama formu, araştırmada kullanılan ölçekler, faktör ve güvenilirlik analizlerine yer verilmektedir.

\subsection{Araştırmanın Amacı ve Önemi}

Araştırmanın temel amacı, çalışanların olumsuz değerlendirilme korkusunun örgütsel sessizlik düzeyleri üzerine olan etkisinin incelenmesidir. Çalışanların kendileri ile ilgili gerek yöneticileri gerekse de çalışma arkadaşları tarafindan nasıl değerlendirildiği, nasıl bir izlenim bıraktığı ve hangi düşünceye sahip oldukları onların örgüt içi davranışlarını etkilemektedir. Olumsuz değerlendirilme korkusu yaşayan çalışanlar yaptıkları işlerde ve kurdukları iletişimlerde başarısız olabilmekte ve örgüt içinde olaylara ve kişilere karşı sessiz kalabilmektedirler. Örgütsel performansın istenilen amaçlar doğrultusunda harekete geçirilebilmesi ve sürdürülebilirliğinin sağlanması için çalışanların olumsuz değerlendirilme korkusuna yol açabilecek ve 
neticesinde onları örgütsel sessizliğe itebilecek nedenlerin araştırılması ve ortadan kaldırılması önem arz etmektedir. Örgütler, rakipleri ile sürdürülebilir rekabet avantajı sağlamak ve amaçlarına ulaşmak için en kıymetli kaynağı olan insana odaklanmalı ve onu olumsuzluğa yöneltebilecek faktörlere karşı gerekli önlemleri almalıdırlar.

\subsection{Araştırmanın Evreni, Örneklemi ve Kısıtları}

Araştırmanın evreni, Kastamonu il merkezinde bulunan bir kamu kurumunda görev yapan 120 çalışandan oluşmaktadır. Araştırmanın yürütüldüğü kamu kurumundaki çalışanların tamamına anket uygulama imkânı bulunduğundan tam sayım yapılmış ve örneklem belirleme yoluna gidilmemiştir. Toplam 120 çalışandan oluşan araştırma evreninin $\alpha=.05$ güven düzeyi ve \pm .05 hata düzeyinde temsil edilebilmesi için en az 92 çalışan ile araştırmanın yürütülmesi yeterli görülmektedir (Altunışık ve diğ., 2004; Gürbüz ve Şahin, 2016). Araştırma sürecinde evrenin tamamına 120 adet anket formu gönderilmiştir. Geri dönüşümü sağlanan 109 anket formu (\%90,8 yanıtlanma oranı) araştırma evrenini temsil edecek niteliktedir. Araştırmanın katılımcıları, veri toplama tekniği ve kullanılan ölçekler araştırmanın sınırları arasında yer almaktadır.

\subsection{Veri Toplama Yöntemi ve Kullanılan Ölçekler}

Araştırma verilerinin toplanmasında anket tekniğinden yararlanılmıştır. Araştırma anketi üç bölümden oluşmakta olup, birinci bölümde çalışanların demografik özellikleri, ikinci bölümde çalışanların olumsuz değerlendirilme korkusu ve son bölümde ise örgütsel sessizlik ile ilişkili sorular yer almaktadır. İkinci ve üçüncü bölümdeki sorular beşli Likert tipinde ölçeklendirilmiştir.

Çalışanların olumsuz değerlendirilme korkusunu ölçmek amacıyla, Leary (1983) tarafından geliştirilen ve Çetin, Doğan ve Sapmaz (2010) tarafından geçerlilik ve güvenilirliği yapılarak Türkçe'ye uyarlanan, Doğan, Sapmaz ve Totan (2011), Çetin ve diğ. (2014), Çelik ve Odacı (2015), Karaşar ve Ögülmüş (2016), Ömür ve diğg. (2016) ve Ünal ve diğ. (2016) tarafından çalışmalarında yararlandıkları “Olumsuz Değerlendirilme Korkusu Ölçeği - Fear of Negative Evaluation Scale” kullanılmıştır. Orijinali 12 madde tek boyuttan oluşan ölçeğin Çetin ve diğ. (2010) tarafindan yapılan Türkçe uyarlamasında bir soru ayırt edicilik indeksi negatif olduğundan ölçekten çıkartılmıştır. Böylece 11 madde olarak belirlenen ölçeğin bu hali ile Türkiye'deki araştırmalarda kullanılabileceği ifade edilmiştir. $\mathrm{Bu}$ çalışmada 11 madde ve tek boyuttan oluşan ölçek formu kullanılmıştır. Ölçekte; "Önemli olmadığını bilsem de başkalarının hakkımda ne düşündüğü beni endişelendirir." ve "Çoğu zaman insanların benim kusurlarımı fark edeceklerinden korkarım.” gibi ifadeler yer almaktadır.

Çalışanların örgütsel sessizlik düzeyini ölçmek amacıyla, Dyne, Ang ve Botero (2003) tarafında geliştirilen, Karacaoğlu ve Cingöz (2009), Taşkıran (2010), Şehitoğlu (2010), Şimşek ve Aktaş (2014) ve Acaray ve diğ . (2015) tarafından çalışmalarında yararlandıkları “Örgütsel Sessizlik Ölçeği- Organizational Silence Scale" kullanılmıştır. Ölçek, 15 madde ve 3 boyuttan oluşmaktadır. Ölçekte; "Benimle ilgili olmadığı için değişime yönelik yapılan öneriler hakkında konuşmakta isteksizimdir.", "Yöneticimin tepkisinden korktuğum veya çekindiğim için iş ile ilgili bilgilerimi kendime saklarım." ve "Bu işletmeye ve iş arkadaşlarıma zarar verebilecek bilgileri açıklamayı reddederim.” gibi ifadeler yer almaktadır. 


\subsection{Faktör ve Güvenilirlik Analizleri}

Araştırma verilerinin toplandığı olumsuz değerlendirilme korkusu ölçeği ve örgütsel sessizlik ölçeğinin iç tutarlılık analizi Cronbach Alfa Katsayısı ile incelenmiştir (Tablo 1). Araştırmada kullanılan ölçeklerin yapı geçerliliğini ölçmek amacıyla doğrulayıcı faktör analizinden yararlanılmıştır (Tablo 2). Ayrıca, verilerin çarpıklık (Skewness) ve basıklık (Kurtosis) değerlerinin -1 ile +1 arasinda bulunduğu ve analizlere uygun olduğu yani normal dağılım gösterdiği söylenebilir (Yazıcıoğlu ve Erdoğan, 2004).

Tablo 1. Güvenilirlik Analizi

\begin{tabular}{lcc}
\hline \hline Ölçek & $\begin{array}{c}\text { Madde } \\
\text { Sayısı }\end{array}$ & $\begin{array}{c}\text { Cronbach } \\
\text { Alpha ( } \boldsymbol{\alpha})\end{array}$ \\
\hline \hline Örgütsel Sessizlik & 15 & $.82,1$ \\
Kabullenici sessizlik & 5 & $.77,7$ \\
Korunma amaçlı sessizlik & 5 & $.85,6$ \\
Koruma amaçlı sessizlik & 5 & $.89,1$ \\
Olumsuz Değerlendirilme Korkusu & 11 & $.82,0$ \\
\hline
\end{tabular}

Tablo 2'de, olumsuz değerlendirilme korkusu ölçeği ve örgütsel sessizlik ölçeğine ilişkin doğrulayıcı faktör analizi sonucu önerilen uyum değerleri sunulmuştur.

Tablo 2. Doğrulayıcı Faktör Analizi

\begin{tabular}{lcccccc}
\hline \hline Ölçek & CMIN/DF & RMSEA & GFI & AGFI & NFI & CFI \\
\hline \hline ODKÖ & 1,953 &, 093 &, 973 &, 900 &, 924 &, 959 \\
\hdashline ÖSÖ & 1,844 &, 088 &, 943 &, 902 &, 913 &, 956 \\
\hline $\begin{array}{l}\text { ODKÖ } \\
\text { ÖSÖ }\end{array}$ & $\begin{array}{l}\text { Olumsuz Değerlendirilme Korkusu Ölçeği } \\
\text { Öroütsel Sessizlik Ölçeği }\end{array}$ & & \\
\hline
\end{tabular}

Olumsuz değerlendirilme korkusu ölçeğinin uyum değerleri incelendiğinde; RMSEA değeri ,093; CMIN/DF değeri 1,953; GFI değeri ,973; AGFI değeri ,900; NFI değeri ,924 ve CFI değeri ,959 olarak hesaplanmıştır. Bu sonuçlara göre ölçek ile daha önceki çalışmalarda Çetin vd. (2010) ortaya konan tek boyutlu faktör yapısını doğrulandığ 1 yani ölçeğin Türkçe'ye uyarlanmış hali ile iyi bir uyum sağladığ1 belirtilebilir. Örgütsel sessizlik ölçeğinin uyum değerleri incelendiğinde; RMSEA değeri ,088; CMIN/DF değeri 1,844; GFI değeri ,943; AGFI değeri ,902; NFI değeri ,913 ve CFI değeri ,956 olarak hesaplanmıştır. Bu sonuçlara göre ölçeğin orijinali ile uyum sağladığı ve üç boyutlu faktör yapısını doğrulandığ ölçeğin de faktör yüklerinin .45 'ten büyük olduğu tespit edilmiştir. 
Olumsuz değerlendirilme korkusu ve örgütsel sessizlik arasındaki ilişkinin incelenmesi için yapılandırılan araştırma modeli Şekil 1'de sunulmuştur.

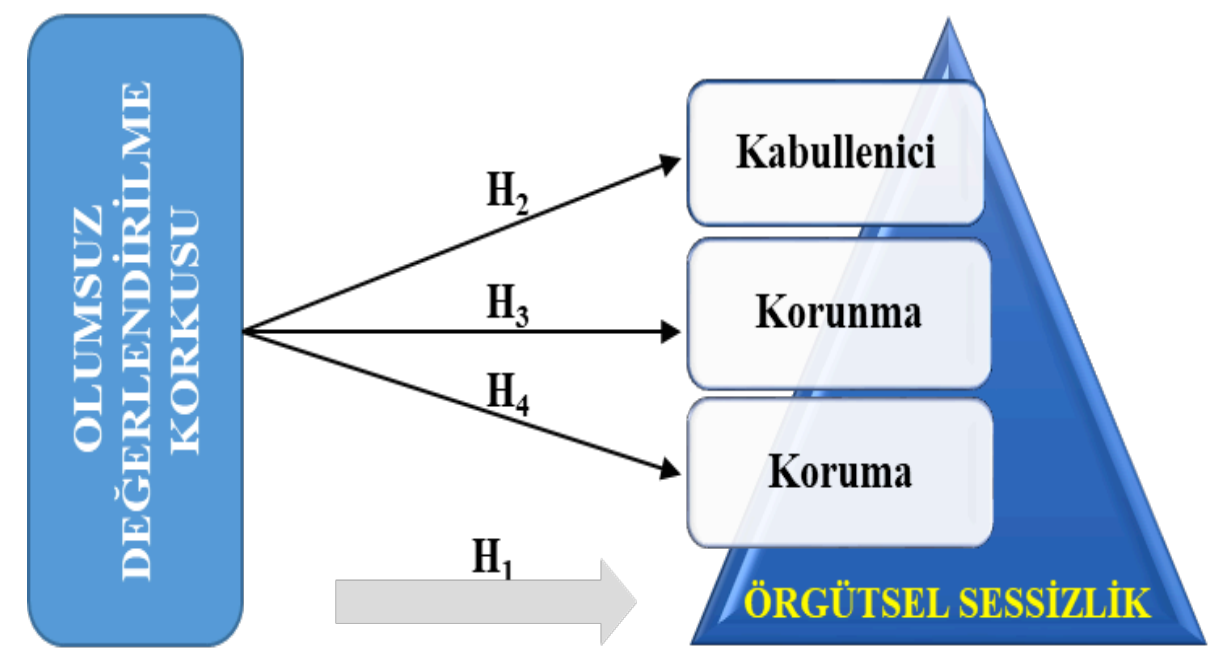

\section{Şekil 1. Araştırma Modeli}

\section{BULGULAR}

$\mathrm{Bu}$ bölümde, bağımsız değişken olumsuz değerlendirilme korkusu ile bağımlı değişken örgütsel sessizlik ve alt boyutları arasındaki ilişkiyi ortaya koymak amaciyla korelasyon analizi (Tablo 3) ve regresyon analizi (Tablo 4 ve 5) kullanılmıştır.

\subsection{Korelasyon Analizi ve Bulguları}

Olumsuz değerlendirilme korkusu ile örgütsel sessizlik ve alt boyutları arasındaki ilişkiyi ortaya koymak amacıyla korelasyon analizinden yararlanılmıştır (Tablo 3).

Tablo 3. Değişkenler Arasındaki Korelasyon Analizi ve Bulguları

\begin{tabular}{|c|c|c|c|c|c|c|c|c|}
\hline \multicolumn{2}{|c|}{ Değişkenler } & \multirow{2}{*}{ Ort. } & \multirow{2}{*}{$\begin{array}{c}\text { SS. } \\
, 736\end{array}$} & \multirow{2}{*}{ 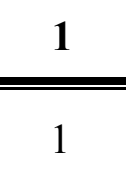 } & \multirow[t]{2}{*}{2} & \multirow[t]{2}{*}{3} & \multirow[t]{2}{*}{4} & \multirow[t]{2}{*}{5} \\
\hline 1 & $\begin{array}{l}\text { Olumsuz Değerlendirilme } \\
\text { Korkusu }\end{array}$ & & & & & & & \\
\hline 2 & Örgütsel Sessizlik & 2,69 & ,561 &, $576^{*}$ & 1 & & & \\
\hline 3 & Kabullenici & 2,61 &, 850 &, $567 *$ &, $683 *$ & 1 & & \\
\hline 4 & Korunma & 2,39 & ,917 &, $466^{*}$ &, $765^{*}$ &, $556^{*}$ & 1 & \\
\hline 5 & Koruma & 3,07 & ,924 & 141 &, $603 *$ & 024 & 093 & 1 \\
\hline
\end{tabular}

${ }^{*} \mathrm{p}<0.01$ düzeyinde anlamlıdır.

Tablo 3'te yer alan, bağımsız değişken olumsuz değerlendirilme korkusu ile bağımlı değişken örgütsel sessizlik ve alt boyutları arasındakikorelasyon analizine ilişskin bulgular incelendiğinde; olumsuz değerlendirilme korkusu ile örgütsel sessizlik arasında anlamlı ve pozitif yönlü $(r=, 576 ; \mathrm{p}<, 01)$ bir ilişkinin olduğu görülmektedir. Olumsuz değerlendirilme korkusu değişkeni ile örgütsel sessizlikalt boyutlarından "kabullenici sessizlik" boyutu $(\mathrm{r}=, 567 ; \mathrm{p}<, 01)$ ve "korunma amaçlı sessizlik" boyutu 
$(\mathrm{r}=, 466 ; \mathrm{p}<, 01)$ arasında pozitif ve anlamlı bir ilişkinin olduğu görülmektedir. Ancak, "koruma amaçlı sessizlik" boyutu ile arasında herhangi bir ilişki gözlenmemiştir.

\subsection{Regresyon Analizi ve Bulguları}

Olumsuz değerlendirilme korkusu ile örgütsel sessizlik ve alt boyutları arasındaki ilişkiyi belirlemek amacıyla regresyon analizinden yararlanılmıştır (Tablo 4 ve 5). Ayrıca Durbin-Watson (DW) istatistiği ile atık değerler arasında otokorelasyon olup olmadiğ 1 kontrol edilmiştir.

Tablo 4. Olumsuz Değerlendirilme Korkusu ile Örgütsel Sessizlik Arasındaki Regresyon Analizi ve Bulguları

Bağımsız Değişken: Olumsuz Değerlendirilme Korkusu

\begin{tabular}{|c|c|c|c|c|c|c|c|}
\hline Bağımlı değişken & $\mathbf{R}^{2}$ & Düz. $\mathbf{R}^{2}$ & $\mathbf{F}$ & $\boldsymbol{\beta}$ & $\mathbf{t}$ & $\mathbf{p}$ & DW \\
\hline Örgütsel Sessizlik & 29,8 & 29,1 & 45,831 &, 546 & 6,770 &, $000 *$ & 1,987 \\
\hline
\end{tabular}

Tablo 4'te yer alan değişkenler arasındaki regresyon analizine ilişkin bulgular değerlendirildiğinde; örgütsel sessizlik değişkeninin\%29,1'inin olumsuz değerlendirilme korkusu değişkeni tarafından açıklandığı görülmektedir. Bu bulgulara göre, çalışanların olumsuz değerlendirilme korkusunun örgütsel sessizlik düzeyleri üzerinde anlamlı ve pozitif yönde $(\beta=, 546, p<, 01)$ etkisinin olduğu görülmektedir. $\mathrm{Bu}$ kapsamda, araştırmanın birinci hipotezi $\left(\mathrm{H}_{1}\right)$ desteklenmektedir. Durbin-Watson istatistiği değerinin 1,987 olduğu ve oto korelasyon olmadığı görülmektedir.

Tablo 5. Değişkenler (Olumsuz Değerlendirilme Korkusu - Örgütsel Sessizlik Boyutları) Arasındaki Regresyon Analizi ve Bulguları

\begin{tabular}{|c|c|c|c|c|c|c|c|c|}
\hline $\begin{array}{l}\text { Bağımsız } \\
\text { Değișken }\end{array}$ & $\mathbf{R}^{2}$ & Düz. $\mathbf{R}^{2}$ & $\mathbf{F}$ & $\boldsymbol{\beta}$ & $\mathbf{t}$ & $\mathbf{p}$ & DW & $\begin{array}{c}\text { Bağımlı } \\
\text { Değişkenler }\end{array}$ \\
\hline \multirow{3}{*}{ 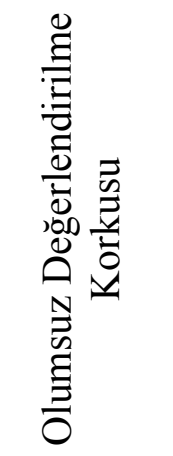 } & 32,1 & 31,5 & 51,089 &, 567 & 7,148 &, $000 *$ & 1,799 & \multirow{2}{*}{$\begin{array}{c}\text { Kabullenici } \\
\text { Korunma }\end{array}$} \\
\hline & 21,7 & 21,0 & 29,949 & ,466 & 5,473 &, $000 *$ & 1,905 & \\
\hline & 0,20 & 0,11 & 2,187 &, 141 & 1,479 &, 142 & 1,784 & Koruma \\
\hline
\end{tabular}

$* \mathrm{p}<0.01$ düzeyinde anlamlıdır. 
Tablo 5'de yer alan değişkenler arasındaki regresyon analizine ilişkin bulgular değerlendirildiğinde; örgütsel sessizlik değişkeninin "kabullenici sessizlik" alt boyutunun \%31,5'inin ve "korunma amaçlı sessizlik" alt boyutunun \%21'ininolumsuz değerlendirilme korkusu değişkeni tarafından açıklandığı görülmektedir. Ancak, örgütsel sessizlik değişkeninin "koruma amaçlı sessizlik" alt boyutu ile olumsuz değerlendirilme korkusu değişkeni arasında herhangi bir ilişki görülmemiştir. Bu bulgulara göre, çalışanların olumsuz değerlendirilme korkusunun örgütsel sessizlik alt boyutlarından kabullenici sessizlik $(\beta=, 567, p<, 01)$ ve korunma amaçlı sessizlik $(\beta=, 466, p<, 01)$ üzerinde anlamlı ve pozitif yönde etkisinin olduğu görülmektedir. $\mathrm{Bu}$ bağlamda, araştırmanın ikinci $\left(\mathrm{H}_{2}\right)$ ve üçüncü $\left(\mathrm{H}_{3}\right)$ hipotezleri desteklenirken, dördüncü hipotezi $\left(\mathrm{H}_{4}\right)$ desteklenmemektedir. Ayrıca, Durbin-Watson istatistiği değerinin 1,5 - 2 değerleri arasında olduğu ve oto korelasyon olmadığı söylenebilir.

Çalışanlarının olumsuz değerlendirilme korkusunun örgütsel sessizlik üzerindeki etkisini ortaya koymak amacıyla oluşturulan araştırma hipotezlerinin yapılan analizler sonucundaki kabul/red durumları Tablo 6'dagörülmektedir.

Tablo 6. Araştırma Hipotezlerinin Kabul/Red Durumları

\begin{tabular}{|c|c|c|c|}
\hline \multirow{2}{*}{$\begin{array}{c}\text { Hipotez } \\
\text { Nu. }\end{array}$} & \multirow{2}{*}{ Hipotezler } & \multicolumn{2}{|c|}{ Durumu } \\
\hline & & Kabul & Red \\
\hline $\mathrm{H}_{1}$ & $\begin{array}{l}\text { Çalışanların olumsuz değerlendirilme korkusunun örgütsel } \\
\text { sessizlik üzerinde pozitif ve anlamlı bir etkisi vardır. }\end{array}$ & & \\
\hline $\mathrm{H}_{2}$ & $\begin{array}{l}\text { Çalışanların olumsuz değerlendirilme korkusunun örgütsel } \\
\text { sessizlik boyutlarından "kabullenici sessizlik" üzerinde } \\
\text { pozitif etkisi vardır. }\end{array}$ & & \\
\hline $\mathrm{H}_{3}$ & $\begin{array}{l}\text { Çalışanların olumsuz değerlendirilme korkusunun örgütsel } \\
\text { sessizlik boyutlarından "korunma amaçlı sessizlik" } \\
\text { üzerinde pozitif etkisi vardır. }\end{array}$ & & \\
\hline $\mathrm{H}_{4}$ & $\begin{array}{l}\text { Çalışanların olumsuz değerlendirilme korkusunun örgütsel } \\
\text { sessizlik boyutlarından "koruma amaçlı sessizlik" üzerinde } \\
\text { pozitif etkisi vardır. }\end{array}$ & & \\
\hline
\end{tabular}

\section{Sonuç ve Değerlendirme}

Örgütler, acımasız rekabet ortamında tüketicilerin beklentilerini en iyi ve hızlı bir şekilde karşılayabilmek, hedeflediği amaçlara ekonomik, etkili ve verimli olarak ulaşabilmek, yaşanan değişim ve gelişime ayak uydurabilmek ve hayatta kalabilmek için en değerli kaynağı olan çalışanlarının bilgi, fikir ve düşüncelerine ihtiyaç duymaktadırlar. Küreselleşen iş dünyasında sadece teknolojik altyapı veya makine örgütlerin istenilen amaçlara ulaşmasında kısıtlı kalmaktadır. Çalışanların bireysel yaratıcılıkları, iç girişimcilik özellikleri, örgütsel bağlılıkları ve fedakârlıkları örgütleri rakiplerine karşı sürdürülebilir rekabet avantajı sağlamada ön plana çıkarmaktadır.

Araştırmanın bulguları değerlendirildiğinde; olumsuz değerlendirilme korkusunun örgütsel sessizlik ve boyutları (kabullenici sessizlik, korunma amaçlı sessizlik) ile güçlü, anlamlı ve pozitif bir ilişkisinin olduğu görülmektedir. Ancak olumsuz değerlendirilme korkusunun örgütsel sessizliğin diğer boyutu olan koruma amaçlı sessizlik boyutu ile herhangi bir ilişkiye rastlanmamaktadır. İş ortamında gerek yönetici, lider veya işverenleri gerekse de diğer iş arkadaşları tarafından bilgi, düşünce, fikir 
ve/veya davranışlarından dolayı olumsuz değerlendirilebileceği korkusu çalışanların sessiz kalma, konuşmama ve/veya davranışta bulunmamasına yol açmaktadır. Yazında yapılmış bazı çalışmalar da araştırmanın bulgularını destekler niteliktedir. Milliken ve diğ. (2003) çalışmalarında, örgütsel sessizliğin en belirgin nedenini çalışanların yöneticileri ve/veya iş arkadaşları tarafindan olumsuz değerlendirilme korkusu ve bunun sonucunda örgüt içinde kurdukları olumlu ilişkilere zarar verme endişesi ya da kaygısı olarak belirtmektedirler. Hazel, Keaten ve Kelly (2014) çalışmalarında, olumsuz değerlendirilme korkusu ile iletişim kuramama ve böylelikle sessiz kalma arasında pozitif ve anlamlı bir ilişkinin olduğunu vurgulamışlardır.

Örgütler, çalışanların fikir ve düşüncelerini her ortamda özgürce ifade edebilmesi için şeffaf ve adil bir örgüt kültürü oluşturmalı ve devamlılığını sağlamalıdırlar. Aynı zamanda yöneticiler çalışanların kararlara katılmasını sağlamalı, onlara değerli olduklarını hissettirmeli ve her konuda destek sağlamalıdırlar. Kendini güvenli ve adaletli bir örgüt kültüründe algılayan çalışan bilgi ve tecrübesini açık ve net bir şekilde örgütün amaçları doğrultusunda kullanabilir. Aynı zamanda örgüt tarafindan iletişim kanalları açık tutulmalı, istek ve şikâyetlere uygun ve mantıklı cevap verilmeli, kararlara katılım sağlanmalı, adil bir ücretlendirme ve motivasyon ortamı oluşturulmalı ve çalışanlara değerli olduğu hissettirilmedir.

\section{Kaynakça}

Acaray, A., Çekmecelioğlu, H. ve Akturan, A. (2015). Örgüt kültürü ile örgütsel sessizlik arasındaki ilişkinin incelenmesi. The Journal of Academic Social Science Studies, 32, 139-157.

Aeen, N. M., Zarei, R. ve Matin, Z. H. (2014). Do the organizational rumors emphasize the influence of organizational silence over organizational commitment? Journal of Social Issues \& Humanities, 2(1), 88-93.

Akgündüz, Y. (2014). Otel çalışanlarının örgütsel sessizliği tercih etmelerinde örgütsel güvenlerinin etkisi. Organizasyon ve Yönetim Bilimleri Dergisi, 6(1), 184-199.

Akın, U ve Ulusoy, T. (2016). The relationship between organizational silence and burnout among academicians: A research on universities on Turkey. International Journal of Higher Education, 5(2), 46-58.

Aktaş, H. ve Şimşek, E. (2014). Örgütsel sessizlik ile algılanan bireysel performans, örgüt kültürü ve demografik değişkenler arasındaki etkileşim. Akdeniz I.I.B.B.F. Dergisi, 28, 24-52.

Aktaş, H. ve Şimşek, E. (2015). Bireylerin örgütsel sessizlik tutumlarında iş doyumu ve duygusal tükenmişlik algılarının rolü. Uluslararası Yönetim İktisat ve Isşletme Dergisi, 11(2), 205-230.

Alparslan, A. M. ve Kayalar, M. (2012). Örgütsel sessizlik: Sessizlik davranışları ve örgütsel ve bireysel etkileri. Mehmet Akif Ersoy Üniversitesi Sosyal Bilimler Enstitüsü Dergisi, 4(6), 136-147.

Altunışık, R., Coşkun, R., Bayraktaroğlu, S. ve Yıldırım, E. (2004). Sosyal bilimlerde araştırma yöntemleri: SPSS uygulamalı. İstanbul: Sakarya Kitabevi.

Amico, K. R., Bruch, M. A., Haese, R. F. ve Sturmer, P. J. (2003). Trait shyness, actualought self-discrepancy and discomfort in social interaction. Personality and Individual Differences, 36(7), 1597-1610. 
Ayan, A. ve Ünsar, S. A. (2015). Olumsuz değerlendirilmekten korkma düzeylerinin belirlenmesi: Bir devlet üniversitesi öğrencileri üzerine araştırma. Manas Sosyal Araştırmalar Dergisi, 4(5), 263-277.

Aydin, S. (2008). An investigation on the language anxiety and fear of negative evaluation among Turkish EFL learners. Asian EFL Journal, 421-444.

Bayın, G., Yeşilaydın, G. ve Esatoğlu, A. E. (2015). Hemşirelerde örgütsel sessizlik nedenlerinin belirlenmesi. İsletme Araştırmaları Dergisi, 7(1), 248266.

Beidel, D. C., Morris, T. L. ve Turner, M. W. (2004). Social phobia. In march. John (Ed.). Anxiety disorder in children and adolescents, 2nd Edition, (141-164). New York: Guilford Publications.

Begley, M. C. ve White, P. (2003). Irish nursing students' changing self-esteem and fear of negative evaluation during their preregistration programme. Journal of Advanced Nursing, 42(4), 390-401.

Bowen, F. ve Blackmon, K. (2003). Spirals of Silence: The Dynamic Effects of Diversity on Organizational Voice. Journal of Management Studies. 40(6), 13931417.

Carleton, R. N., Collimore, K. C. ve Asmundson, G. J. G. (2007). Social anxiety and fear of negative evaluation: Construct validity of the BFNE-II. Journal of Anxiety Disorders, 21, 131-141.

Chu, C., Buchman-Schmitt, J. M., Moberg, F. B. ve Joiner, T. E. (2016). Thwarted belongingness mediates the relationship between fear of negative evaluation and suicidal ideation. Cog. Ther. Res. 40, 31-37.

Collins, A. K., Westra, A. H., Dozois, J. A. D. ve Stewart, H. S. (2005). The validity of the brief version of the Fear of Negative Evaluation Scale. Anxiety Disorders, 19, 345-359.

Çakıcı, A. (2008). Örgütlerde sessiz kalınan konular, sessizliğin nedenleri ve algılanan sonuçları üzerine bir araştırma. Çukurova Üniversitesi Sosyal Bilimler Enstitüsü Dergisi, 17(1), 117-134.

Çakıcı, A. (2010). Örgütlerde iş gören sessizliği, neden sessiz kalmayı tercih ediyoruz? Ankara: Detay Yayıncilık.

Çakınberk, A. K., Dede, N. P. ve Yılmaz, G. (2014). Relationship between organizational trust and organizational silence: An example of public university. Journal of Economics Finance and Accounting, 1(2), 91105.

Çam, S., Sevimli, D. ve Yerlikaya, E. E. (2010). Olumsuz değerlendirilmekten korkma ölçeği'ne (ODKÖ) ilişkin bir geçerlik ve güvenirlik çalışması. Ç. Ü. Sosyal Bilimler Enstitüsü Dergisi, 19 (1), 132-140.

Çavuş, F. M., Develi, A. ve Sarıoglu, S. G. (2015). Mobbing ve örgütsel sessizlik: Enerji sektörü çalışanları üzerine bir araştırma. İşletme ve İktisat Çalışmaları Dergisi, 3(1), 10-20.

Çavuşoğlu, S. ve Köse, S. (2016). Örgüt kültürünün örgütsel sessizlik davranışına etkisi Dokuz Eylül Üniversitesi Sosyal Bilimler Enstitüsü Dergisi, 18(1), 115-146.

Çelik, B. Ç. ve Odacı, H. (2015). Akademik erteleme davranışının bazı kişisel ve psikolojik değişkenlere göre açıllanması. Hacettepe Üniversitesi Eğitim Fakültesi Dergisi, 30(3), 31-47. 
Çetin, B., Doğan, T. ve Sapmaz, F. (2010). Olumsuz değerlendirilme korkusu ölçeği kısa formu'nun Türkçe uyarlaması: Geçerlik ve güvenirlik çalışması. Eğitim ve Bilim, 35(156), 205-216.

Çetin, B. İlhan, M. ve Y1lmaz, F. (2014). Olumsuz değerlendirilme korkusu ve akademik risk alma arasındaki ilişkinin kanonik korelasyonla incelenmesi. Kuram ve Uygulamada Ë̆itim Bilimleri, 14(1), 135-158.

Çınar, O., Karcıoğlu, F. ve Alioğulları, Z. D. (2013). The relationship between organizational silence and organizational citizenship behavior: A survey study in the province of Erzurum, Turkey. Procedia-Social and Behavioral Sciences, 99, 314-321.

Dimitris, B. ve Vokala, M. (2007). Organizational silence: A new challenge for human resource management. Athense university of Economics and Business, 1-19.

Doğan, T. ve Totan, T. (2010). Olumlu değerlendirilme korkusu ölçeği Türkçe formu'nun geçerlik ve güvenirlik çalışması. Uluslararası Hakemli Sosyal Bilimler E-Dergisi, 22, 1-20.

Doğan, T., Sapmaz, F. ve Totan, T. (2011). Beden imgesi baş etme stratejileri ölçeğinin Türkçe uyarlaması: Geçerlilik ve güvenilirlik çalışması. Anadolu Psikiyatri Dergisi, 12, 121-129.

Donaghey, J., Cullinane, N., Dundon, T. ve Wilkinson, A. (2011). Reconceptualising Employee Silence. Problems and Prognis. Work, Employment and Society, 25(1), 51-67.

Duke, D., Krishnan, M., Faith, M. ve Storch, A. E. (2006). The psychometric properties of the brief fear of negative evaluation. Anxiety Disorders, 20, 807-817.

Durmuş, E. (2008). Yaratıcı drama ile bütünleştirilmiş grupla psikolojik danışmanın üniversite öğrencilerinin utangaçlık düzeylerine etkisi. Ankara Üniversitesi Ĕgitim Bilimleri Fakültesi Dergisi, 41(1), 93-114.

Dyne, L. V., Ang S. ve Botero I. C. (2003). Conceptualizing employee silence and employee voice as multidimensional constructs. Journal of Management Studies, 40(6), 1359-1392.

Elçi, M. Erdilek K., Alpkan L. ve Şener I. (2014). The mediating role of mobbing on the relationship between organisational silence and turnover intention. ProcediaSocial and Behavioural Sciences 150, 455-464

Erdoğan, Ö. ve Uçukoğlu, H. (2011). İlköğretim okulu öğrencilerinin anne-baba tutumu algıları ile atılganlık ve olumsuz değerlendirilmekten korkma düzeyleri arasındaki ilişkiler. Kastamonu Eğitim Dergisi, 19(1), 51-72.

Erigüç, G., Özer, S., Sonğur, C. ve Turaç, S. İ. (2014). Bir devlet hastanesinde hemşirelerde örgütsel sessizlik üzerine bir araştırma. Çankırı Karatekin Üniversitesi İktisadi ve İdari Bilimler Fakültesi Dergisi, 4(2), 61-84.

Erkan, Z. (2002). Sosyal kaygı düzeyleri yüksek ve düşük ergenlerin ana baba tutumlarına ilişkin nitel bir çalışma. Çukurova Üniversitesi Sosyal Bilimler Enstitüsü Dergisi, 10(10), 120-133.

Erol, G. ve Köroğlu, A. (2013). Liderlik tarzları ve örgütsel sessizlik ilişkisi: Otel işletmelerinde bir araştırma. Seyahat ve Otel İsletmeciliği Dergisi, 10(3), 45-64. 
Fard, P. G. ve Karimi, F. (2015). The relationship between organizational trust and organizational slience with job satisfaction and organizational commitment of the employees of university. International Education Studies, 8(11), 219-227.

Gül, H. ve Özcan, N. (2011). Mobbing ve örgütsel sessizlik arasındaki ilişkiler: karaman il özel idaresinde görgül bir çalışma. Kahramanmaraş Sütçü İmam Üniversitesi İktisadi ve İdari Bilimler Fakültesi Dergisi, 1(2), 107- 134.

Gürbüz, S. ve Şahin, F. (2016). Sosyal bilimlerde araştırma yöntemleri. Ankara: Seçkin Yayıncilik.

Hamarta, E. (2009). Ergenlerin sosyal kaygılarının kişilerarası problem çözme ve mükemmeliyetçilik açısından incelenmesi. Illköğretim Online, 8(3), 729-740.

Hazel, M., Keaten, J. ve Kelly, L. (2014). The relationship between personality temperament, communication reticence, and fear of negative evaluation. Communication Research Reports, 31(4), 339-347.

Karacaoglu, K. ve Cingöz, A. (2009). İşgören sessizliğinin kaynağı olarak liderlik davranışı ve örgütsel adalet algısı. 17. Ulusal Yönetim ve Organizasyon Kongresi, Osmangazi Üniversitesi, Eskişehir.

Karacaoğlu, K. ve Küçükköylü, C. (2015). İşgören sessizliğinin örgütsel sinizme etkisi: Kamu çalışanları üzerine bir araştırma. Ege Akademik Bakış, 15(3), 401-408.

Karaşar, B. ve Ögülmüş, S. (2016). Sosyal onay ihtiyacı ölçeği: Geçerlik ve güvenirlik analizi. Ege Eğitim Dergisi, 17(1), 84-104.

Kilıçlar, A. ve Harbalıŏlu, M. (2014). Örgütsel sessizlik ve örgütsel vatandaşlık davranışı arasındaki ilişki: Antalya'daki beş yıldızlı otel işletmeleri üzerine bir araştırma. Işsletme Araştırmaları Dergisi, 6(1), 328-346.

Korkmaz, O. ve Aydemir, S. (2015). Örgütsel sessizlik ve örgütsel vatandaşlık davranışı arasındaki ilişkinin belirlenmesine yönelik bir araştırma. Yönetim ve Ekonomi Araştırmaları Dergisi, 13(2), 140-165.

Köse, E., Bayköse, N., Turan, B. E. ve Lapa, Y. T. (2016). Düzenli egzersiz yapan bireylerde olumsuz değerlendirilme korkusunun vücut algılarını belirlemedeki rolü. Mediterranean Journal of Humanities, VI(2), 351-360.

Leary, M. L. (1983). Social anxiousness: The construct and its measurement. Journal of Personality Assessment, 47(1), 66-75.

Mesagno, C., Harvey, T. J. ve Janelle, M. C. (2012). Choking under pressure: The role of fear of negative evaluation. Psychology of Sport and Exercise, 13, 60-68.

Milliken, F. J. ve Morrison, E. W. (2003). Shades of silence: Emerging themes and future directions for research on silence in organizations. Journal of Management Studies, 40(6), 1564-1568.

Milliken, F. J., Morrison, E. W. ve Hewlin, P. F. (2003). An exploratory study of employee silence: issues that employees don't communicate upward and why. Journal of Management Studies, 40(6), 1453-1476.

Morrison, E. W. ve Milliken, F. J. (2000) Organizational silence: A barrier to change and development in a pluralistic world, The Academy of Management Review, 25(4), 706-725.

Nakane, I. (2006). Silence and politeness in intercultural communication in university seminars. Journal of Pragmatics, 38(11), 1811-1835. 
Nikmaram, S., Yamchi, G. H., Shojaii, S., Zahrani, A. M. ve Alvani, M. S. (2012). Study on relationship between organizational silence and commitment in Iran. World Applied Sciences Journal, 17(10), 1271-1277.

Ömür, Y. E., Aydın, R. ve Argon, T. (2014). Öğretmen adaylarının olumsuz değerlendirilme korkuları ile akademik sahtekârlık eğilimleri arasındaki ilişki. Eğitim ve İnsani Bilimler Dergisi: Teori ve Uygulama, 5(9), 131-149.

Özgüngör, S. (2006). Öz bilinç, olumsuz değerlendirilme korkusu, performans odaklı sınıf algısı ve not yönelimi. Pamukkale Üniversitesi Eğitim Fakültesi Dergisi, 19, $1-8$.

Özyer, K. (2017). Örgütsel sessizlik. (Ed. S. Polatçı ve K. Özyer) içinde 21. Yüzyılda Örgütsel Davranış. İstanbul: Beta Yayınevi.

Panahi, B., Veiseh, S., Divkhar, S. ve Kamari, F. (2012). An empirical analysis on influencing factors on organizational silence and its relationship with employee's organizational commitment. Management Science Letters, 2(3), 735-744.

Pinder, C. C. ve Harlos, H. P. (2001). Employee silence: Quiescense and acquiescence as responsesto perceived injustice. Research in Personnel and Human Resource Management, 20, 331-69.

Puklek, M. ve Vidmar, G. (2000). Social anxiety in slovene adolescents: Psychometric properties of a new measure, age differences and relations with self-consciousness and perceived incompetence. European Review of Applied Psychology, 50,249258.

Quinn, R. ve Spreitzer, G. (1997). The road to empowerment: Seven questions every leader should answer. Organizational Dynamics, 26(2), 37-50.

Rapee, R. M. ve Heimberg, R. G. (1997). A cognitive - behavioral model of anxiety in social phobia. Behavioral Research and Therapy, 35(8), 741-756.

Ridgers, D. N., Fazey, M. A. D. ve Fairclough, J. S. (2007). Perceptions of athletic competence and fear of negative evaluation during physical education. British Journal of Educational Psychology, 77, 339-349.

Scott, R. L. (1993). Dialectical tensions of speaking and silence. The Quarterly Jorunal of Speech, 79, 1-18.

Seçer, İ., Halmatov, S. ve Gençdoğan, B. (2013). Duygusal tepkisellik ölçeğinin Türkçeye uyarlanması: Güvenirlik ve geçerlilik çalışması. Sakarya University Journal of Education, 3(1), 77-89.

Sevimli, D. (2009). Beden eğitimi ve spor yüksekokulu özel yetenek sınavına katılan adayların olumsuz değerlendirilme korkusunun araştırılması. Türkiye Klinikleri J Sports Sci, 1(2), 88-94.

Şehitoğlu, Y. (2010). Örgütsel sessizlik örgütsel vatandaşlık davranışı ve algılanan çalışan performansı ilişkisi. Yayımlanmamış Doktora Tezi, Gebze Yüksek Teknoloji Enstitüsü, Gebze.

Şimşek, E. ve Aktaş, H. (2014). Örgütsel sessizlik ile kişilik ve yaşam doyumu etkileşimi: Kamu sektöründe bir araştırma. Anadolu Üniversitesi Sosyal Bilimler Dergisi, 14(2), 121-136.

Taşkıran, E. (2010). Liderlik tarzının örgütsel sessizlik üzerindeki etkisinde örgütsel adaletin rolü ve bir araştırma. Yayımlanmamış Doktora Tezi, Marmara Üniversitesi, İstanbul. 
Teachman, A. B. ve Allen, P. J. (2007). Development of social anxiety: Social interaction predictors of implicit and explicit fear of negative evaluation. $J$ Abnorm Child Psychol, 35, 63-78.

Türkçapar, M. H. (1999). Sosyal fobinin psikolojik kuramı. Klinik Psikiyatri, 2, 247253.

Ünal, E., Arık, S. ve Uzun, B. (2016). Sınıf ve sosyal bilgiler eğitiminde öğrenim gören öğretmen adaylarının olumsuz değerlendirilme korkuları. Adlyaman Üniversitesi Sosyal Bilimler Enstitüsü Dergisi, 8(22), 289-307.

Vakola, M. ve Bouradas, D. (2005). Antecedents and consequences of organizational silence: An empirical investigation. Employee Relations, 27(5), 441-458.

Watson, D. ve Friend, R. (1969). Measurement of social-evaluative anxiety. Journal of Consulting and Clinical Psychology, 33, 448-457.

Weeks, J. W., Heimberg, R. G., Fresco, D. M., Hart, T. A., Turk, C. L., Schneier, F. R. ve Liebowitz, M. R. (2005). Empirical validation and psychometric evaluation of the brief fear of negative evaluation scale in patients with social anxiety disorder. Psychological Assessment, 17(2), 179-190.

Weeks J. W., Heimberg, R. G. ve Rodebaugh, T. L. (2008). The fear of positive evaluation scale: Assessing a proposed cognitive component of social anxiety disorder. Journal of Anxiety Disorders, 22, 44-55.

Williams, K. C., Falum, E. ve Martinsen, E. W. (2015). Fear of negative evoluation, avoidance and mental distress among hearing-impaired employees. Rehabilitatin Psychology, 60(1), 51-58.

Yazıcıŏglu, Y. ve Erdoğan, S. (2004). SPSS Uygulamalı Bilimsel Araştırma Yöntemleri. Ankara: Detay Yayıncılik.

Zehir, C. ve Erdoğan, E. (2011). The association between organizational silence and ethicalleadership through employee performance. Procedia Social and Behavioral Sciences, 24,1389-1404.

Zorbaz, O. ve Dost, T. M. (2014). Lise öğrencilerinin problemli internet kullanımının cinsiyet, sosyal kaygı ve akran ilişkileri açısından incelenmesi. Hacettepe Üniversitesi Ë̆itim Fakültesi Dergisi, 29(1), 298-310. 


\title{
Effect of Fear of Negative Evaluation of Employees on Organizational Silence
}

\author{
Engin KANBUR \\ Kastamonu University \\ School of Civil Aviation \\ Kastamonu, Turkey \\ orcid.org/0000-0002-6261-9314 \\ ekanbur@kastamonu.edu.tr
}

\section{Extensive Summary}

\section{Introduction}

In the global business world where intense competition is taking place, organizations are in need of experienced, responsible, creative, motivated, committed and innovative employees who are knowledgeable and willing to share this in order to meet consumers' expectation in the best and speedy manner without sacrificing quality, to gain a sustainable competitive advantage against their competitors, to become leader in the industry and to create a positive image (Quinn and Spreitzer, 1997). The ability of employees to have these skills and use them easily and freely within the organization is possible by removing organizational and managerial barriers, by creating a positive organizational culture and by providing the necessary support from the organization (Dimitris and Vakola, 2007).

Employees are able to work more effectively and efficiently in organizations inwhich that they are valued, their participation to decisions is provided, their ideas, thoughts and knowledges are shared freely, their behavior is not underestimated, organizational justice is fully provided, and thus, their performances may become high. On the contrary of these cases, at any time when encountered to a problem or an opportunity employees may consciously exhibit silence behavior in order to protect themselves from harm and danger that may arise and to avoid from being excluded and being worthless. Fear of negative evaluation is one of the factors that constitute the basis of silence, nonspeaking and/or unresponsiveness behavior of employees in front of the events (Milliken and Morrison, 2003).

Fear of negative evaluation is defined as the consideration of others' negative evaluations about the performance, abilities and behaviors of the individual, and living distress, anxiety and fear due to these and avoidance from such environments (Erdoğan and Uçukoğlu, 2011; Leary, 1983). Organizational silence can be clarified as a form of behavior which employees made consciously, actively and in a way oriented towards an aim.Organizational silence can be defined as hiding or not telling ideas, thoughts and knowledge about behavioral, emotional and/or cognitive evaluations against manager, boss, leader and other individuals who have the ability of problem solving and influencing organizational change and development (Çakıc1, 2008; Erigüç et al., 2014). While it is expected from employees to have creativity, internal entrepreneurship characteristics, more knowledge sharing, higher organizational commitment and higher 
job satisfaction, and therefore increased organizational performance in the context of modern management approaches, it can be seen that employees are unconcerned and in silence consciously against organization due to various reasons. This silence behavior of employees negatively affects the rise of new and creative ideas and the formation of synergy (Çavuşoğlu and Köse, 2016). In this context, the following research hypotheses have been established in order to understand the relationship between fear of negative evaluation and organizational silence and its dimensions.

$\mathbf{H}_{1}$ : The fear of negative evaluation of employees has a positive and significant effect on organizational silence.

$\mathbf{H}_{2}$ : The fear of negative evaluation of employees has a positive and significant effect on "acquiescent silence" dimension of organizational silence.

$\mathbf{H}_{3}$ : The fear of negative evaluation of employees has a positive and significant effect on "defensive silence" dimension of organizational silence.

$\mathbf{H}_{4}$ : The fear of negative evaluation of employees has a positive and significant effect on "prosocial silence" dimension of organizational silence.

\section{Methodology}

The main purpose of the research is to examine the effect of employees' fear of negative evaluation on their organizational silence levels. The population of the research consists of 120 employees working in a public institution located in Kastamonu province city center. Due to possibility of reaching the whole of the employees in this public institution, full enumeration utilized in the research. In the research process, 120 questionnaires were sent to the population of the research. 109 recycled questionnaire forms $(90.8 \%$ response rate) statistically accepted to represent the population. Participants, data gathering technique and measures can be clarified as the limitations of the study. For gathering the data questionnaire technique was used. The research questionnaire consists of three parts; the first part is related to the demographic characteristics of the employees, the second part is measuring the fear of negative evaluation and the last part is related to organizational silence. The questions in the second and third part were scaled in the five-point Likert type. In order to measure the fear of negative evaluation of the employees, "Fear of Negative Evaluation Scale" which has been developed by Leary (1983) and adapted to Turkish by Çetin et al. (2010) was used. The scale consists of 11 items and one dimension. "Organizational Silence Scale", developed by Dyne, Ang and Botero (2003), was used to measure the organizational silence level of employees. The scale consists of 15 items and 3 dimensions. The internal consistency analyses of the scales of fear of negative evaluation and organizational silence were examined with Cronbach Alpha and found over $70 \%$. Additionally, confirmatory factor analysis results of the scales showed good fit values.

\section{Findings}

Findings of correlation and regression analyses which were conducted for understanding the relationships between fear of negative evaluation and organizational silence and its dimensions were examined. When correlation analysis findings related to the variables are examined, it can be seen that there is a significant and positive relationship $(\mathrm{r}=, 576 ; \mathrm{p}<, 01)$ between fear of negative evaluation and organizational silence. Findings demonstrate that there is a significant and positive relationship between fear of negative evaluation and acquiescent silence $(r=, 567 ; \mathrm{p}<, 01)$ and 
defensive silence $(\mathrm{r}=, 466 ; \mathrm{p}<, 01)$. However, no relation is observed between prosocial silence. When the findings of the regression analysis between the variables are evaluated, it can be seen that $29,1 \%$ of organizational silence is explained by fear of negative evaluation. According to these findings, fear of negative evaluation of employees has a significant and positive effect on their organizational silence levels ( $\beta$ $=, 546, \mathrm{p}<, 01)$. Thus, the first hypothesis $\left(\mathrm{H}_{1}\right)$ of the research is supported. When the findings of the regression analysis betweenfear of negative evaluation and subdimensions of organizational silence are examined, it can be seen that $31,5 \%$ of acquiescent silence and $21 \%$ of defensive silence is explained by fear of negative evaluation. However, there isn't any relationship found between prosocial silence and fear of negative evaluation. According to these findings, fear of negative evaluation of employees has a significant and positive effect on their acquiescent silence $(\beta=, 567$, $\mathrm{p}<, 01)$ and defensive silence $(\beta=, 466, \mathrm{p}<, 01)$ levels. Thus, the second $\left(\mathrm{H}_{2}\right)$ and the third hypotheses $\left(\mathrm{H}_{3}\right)$ of the research are supported while the fourth hypothesis $\left(\mathrm{H}_{4}\right)$ is rejected.

\section{Conclusion and Discussion}

When the findings of the research are evaluated; there appears to be a strong, significant and positive relationship between fear of negative evaluation and organizational silence and its subdimensions (acquiescent silence and defensive silence). However, no relation is observed between fear of negative evaluation and prosocial silence as a subdimension of organizational silence. Employees fear that they may be negatively evaluated by their managers, leaders or employers as well as by other colleagues due to their knowledge, thoughts, ideas and/or behaviors in the business environment cause them to be in silence, nonspeaking and/or unresponsiveness behavior. Organizations must establish and maintain a transparent and equitable organizational culture for their employees to express their opinions and ideas freely in every environment. At the same time, managers must make employees participate in decisions, feel them that they are valuable and provide them support in all matters. Employees who clearly perceive themselves in a safe and equitable organizational culture can clearly and confidently use their knowledge and experience in the direction of their organization's purposes. Ultimately, communication channels should be kept open, appropriate and logical answers should be given to requests and complaints, participation in decisions should be ensured, fairminded compensation and motivation should be provided and employees should feel valued by the organization. 